\title{
TEMPO PRESENTE BRASILEIRO: cultura política, ditaduras e historiografia na perspectiva de Rodrigo Patto Sá Motta
}

\author{
Emerson César de Campos* \\ Luiz Felipe Falcão* \\ Reinaldo Lindolfo Lohn ${ }^{* * *}$
}

Rodrigo Patto Sá Motta é Professor do Departamento e do Programa de PósGraduação em História da Universidade Federal de Minas Gerais (UFMG) e Pesquisador do Conselho Nacional de Desenvolvimento Científico e Tecnológico (CNPq). Sua formação acadêmica ocorreu na própria UFMG, na Universidade de São Paulo (Doutorado em História Econômica) e na Universidade de Maryland, nos EUA (Pós-Doutorado). Em Maryland e também na Universidade de Santiago do Chile atuou como professor visitante. A prática docente e a produção acadêmica do Professor Rodrigo Patto Sá Motta concentram-se principalmente na área de História do Brasil contemporâneo, sob a perspectiva de uma História Política renovada, a qual leva em conta tanto temas clássicos como novas abordagens para o estudo de representações, práticas sociais e cultura política. Autor de uma profícua produção bibliográfica acerca de temas relativos aos conflitos políticos que marcaram a instauração da ditadura militar no Brasil, em 1964, foi convidado pelo Programa de Pós-graduação em História da UDESC a proferir palestra, em fins de 2010, sobre o tema "História e memória nas ditaduras”. Na mesma ocasião, dispôs-se a conceder esta entrevista

\footnotetext{
* Doutor em História pela Universidade Federal de Santa Catarina. Professor da Universidade do Estado de Santa Catarina. E-mail: emecampus@yahoo.com.br

** Doutor em História Social pela Universidade de São Paulo. Professor da Universidade do Estado de Santa Catarina. E-mail: luizfelipe@lycos.com

*** Doutor em História pela Universidade Federal do Rio Grande do Sul. Professor da Universidade do Estado de Santa Catarina. E-mail: reilohn@hotmail.com
} 
para Tempo e Argumento, conduzida pelos professores Emerson Cesar de Campos, Luiz Felipe Falcão e Reinaldo Lindolfo Lohn, na qual apresenta suas reflexões acerca de temas variados que perpassam a cultura política e suas implicações para a compreensão das especificidades da ditadura militar brasileira e suas congêneres no Cone Sul. Também expôs suas perspectivas acerca do diálogo entre campos disciplinares, escrita da História e novos temas de pesquisa suscitados pela reflexão sobre o tempo presente brasileiro.

Tempo e Argumento: Como a discussão recente sobre a História política articula-se com sua própria trajetória acadêmica?

Rodrigo Patto Sá Motta: Quando eu comecei a graduação, a História política era mal vista. Mas era o que eu queria a fazer, o que eu continuo fazendo e o que me atrai: entender os fenômenos do poder, a disputa pelo poder, a construção do Estado, projetos políticos, disputas, hegemonia, conflitos, guerras, eleições, golpes, ditadura, democracia, essas são as temáticas que me atraem. Agora, na minha trajetória eu também aprendi a alargar essa visão da História política abarcando temas mais próximos da História cultural, o fenômeno da representação, da cultura visual e da construção da imagem. A minha trajetória é uma tentativa tanto de tratar a política de uma forma clássica, ou seja, através do estudo de instituições políticas, disputa pelo poder político, poder do Estado, e, ao mesmo tempo, fazer pesquisa com um olhar mais abrangente: o cultural no político. Isso inclui o conceito cultura política. Por história cultural do político eu entendo uma história de representações políticas: o que os projetos políticos elaboram para conseguir adesão, a propaganda. O meu interesse pela história política sempre foi por temas contemporâneos. Tenho certo gosto pela polêmica e por temas mais próximos de nós, coisas que geram polêmica, o que tem a ver com o fato de eu ter tido militância política quando jovem.

Tempo e Argumento: Quais seus principais interlocutores nesta trajetória de discussões sobre a História recente do Brasil?

Rodrigo Patto Sá Motta: Entre os historiadores acadêmicos, a interlocução não é tão imediata e evidente. Na nossa disciplina existe uma tensão em relação a temas mais próximos de nós. Há uma abordagem tradicional segundo a qual o objeto da História não pode estar muito próximo temporalmente. Então, quem trabalha com temas como os que me interessam 
encontra muitos interlocutores nas Ciências Sociais, na Sociologia, na Sociologia Política, na Antropologia Política e também na Filosofia. Eu tenho a estratégia de buscar interlocução nesses campos. Mas eu acho que os historiadores estão ficando mais interessados nos temas recentes, então a interlocução vai ficar mais fácil. Deve-se levar em consideração que há uma mudança de geração. Por exemplo, há muita gente da faixa de trinta anos que nasceu quando a ditadura estava quase acabando e, por isso, tem certo distanciamento em relação ao assunto. A ideia de que a História demanda um distanciamento é, de fato, importante, embora eu tenha uma ressalva sobre isso. Pesquisar a sua própria história não é uma coisa muito simples: quem faz pesquisa de seu próprio tempo e de sua própria experiência corre o risco de misturar a memória com a História e seu envolvimento pessoal com o assunto influenciará o resultado. Então eu acho que deve haver certo distanciamento, inclusive do ponto de vista temporal, mas também acredito que é perfeitamente possível estudar temas de 20, 30 ou 40 anos e, principalmente, as gerações mais jovens têm mais facilidade para isso. Acredito que a história continua sendo uma disciplina que desenvolve a perspectiva crítica a partir de um certo distanciamento, então eu acho que, com o interesse dessas novas gerações, os interlocutores tendem a aumentar. A quantidade de jovens que querem fazer mestrado e doutorado em temas de História recente aumentou sensivelmente. Inclusive porque os jovens estão em busca de temas novos: é também uma estratégia de construir carreiras, a partir de escolhas por temas que sejam novidades.

Tempo e Argumento: Como é possível lidar com as diferenças entre a linguagem e a abordagem das Ciências Sociais em relação à historiografia?

Rodrigo Patto Sá Motta: Isso não é tão simples. As Ciências Sociais criam modelos e teorias gerais, querem encontrar explicações gerais para os fenômenos, através da criação de conceitos, enquanto a historiografia tem a perspectiva de investir na singularidade de temas e objetos. Além disso, uma questão chave para a História é o fator tempo: desenvolver um recorte temporal. O tempo é uma referência de análise: a partir um recorte temporal, verifico o que mudou e observo as permanências. O tempo é uma dimensão fundamental para o historiador, enquanto para as Ciências Sociais o tempo é secundário. No interior das regularidades os cientistas sociais procuram fenômenos não influenciados pelo tempo, como as leis gerais da família ou do mercado. Mas também acredito que nos aproximamos das Ciências Sociais quando adotamos certos conceitos muito úteis, como é o caso do conceito de cultura política. A história política envolve discussões sobre poder político e isso aponta para 
diálogos, não só com as Ciências Sociais, mas também com a Filosofia Política. São campos que se aproximam do olhar da historiografia ao estudar determinados fenômenos políticos mais recentes. No entanto, acredito que o olhar do historiador pode contribuir para corrigir algumas generalizações excessivas. Um exemplo é a utilização do conceito de Doutrina da Segurança Nacional nas análises sobre a ditadura militar. É um conceito fundamental para pensar o período, mas, a depender da forma como é empregado, corre-se risco mais de engessar do que de explicar o tema. Apontar que as ditaduras brasileira, chilena, argentina ou uruguaia eram, basicamente, a mesma coisa, como muitos cientistas sociais tendem a pensar, através da aplicação da noção de estado de segurança nacional, simplifica demais a discussão, porque isso leva à perda das especificidades de cada caso e da riqueza da análise.

Tempo e Argumento: Você pensaria num possível tempo presente brasileiro a partir dos acontecimentos e processos que envolveram o golpe civil-militar de 1964 ?

Rodrigo Patto Sá Motta: Acredito que se precisássemos escolher um marco para um tempo presente no Brasil, 1964 seria uma escolha consistente. Seu impacto foi inquestionável, não só no Brasil, mas na América Latina. Há muitos historiadores e cientistas sociais dos países vizinhos que entendem que o ciclo de ditaduras na América Latina começou com o Brasil. Isso precisa ser pesquisado mais profundamente, mas mesmo nos Estados Unidos foi visto como um momento chave. No Brasil, 1964 inicia um período de inflexão nas relações do Estado com a sociedade. Contudo, também é necessário atentar para as continuidades: o Estado mudou bastante, mas manteve muitos elementos que estavam estruturados, por vezes os intensificando. É o caso da intervenção na economia: o modelo estava instalado, os militares o aguçaram de maneira autoritária. O modelo econômico baseado no famoso tripé, capital multinacional, estatal e nacional, não foi inventado em 1964. Isso estava configurado no período de Juscelino Kubitscheck. Mas evidentemente há uma mudança importantíssima no cenário brasileiro no que diz respeito ao Estado porque se instala um estado mais autoritário do que o padrão histórico brasileiro, um Estado dominado pelos militares. Foi, evidentemente, uma ditadura civil-militar. Em qualquer ditadura sempre há os civis, pois não é possível aos militares governarem sem apoio civil e, no caso brasileiro, a presença de civis foi muito importante em todas as esferas. Mas foi uma ditadura com hegemonia militar: quem comandava e tomava as decisões eram os militares e a corporação militar controlou o poder, embora em associação com os civis. Até então, houve momentos não tão claros ou efêmeros de regimes militares no Brasil, como os casos de Deodoro da Fonseca ou Floriano Peixoto. 
Getúlio Vargas se apoiou nos militares desde 1930 e, principalmente, em 1937. Mas é em 1964 que se percebe um papel diferenciado dos militares no poder, embora com continuidades: autoritarismo, repressão e, principalmente, um hiato entre a política e a cidadania. Enfim, o regime civil-militar brasileiro é um marco, nós lidamos com esse legado até hoje, inclusive no que toca a questão da memória. Uma das grandes discussões no cenário político atual diz respeito à superação ou não do regime militar: os atores políticos de hoje tiveram passagem por aquele período, uns no campo da oposição, outros no campo de governo. Enfim, ao pensar em tempo presente, o regime militar é um marco muito forte, como para os franceses foi a Segunda Guerra ou 1968. É interessante que estudiosos da Argentina e do Uruguai estejam trabalhando com o conceito de história recente e, para eles, história recente começa nos anos de 1960. Não se referindo apenas a golpes, mas pensando em embates entre esquerda e direita e intervenções autoritárias. 1964 é, portanto, um marco interessante, mas sem perder a dimensão da continuidade. Mesmo no que diz respeito à repressão e ao aparato repressivo, as leis de segurança foram herdadas ainda do regime de Vargas: a primeira lei de segurança, que alguns chamam de Lei de Segurança Nacional, foi editada em 1935. Depois houve outra em 1953 e os militares reformaram a lei em 1967 e em 1969. Os DOPS [Departamento de Ordem Política e Social], que foram usados no golpe de 1964, vinham dos anos de 1920 e 1930. Depois os militares criaram os outros aparatos federais, mas eles também se espelharam na experiência dos DOPS.

Tempo e Argumento: No seu atual projeto de pesquisa, qual a importância da História Oral?

Rodrigo Patto Sá Motta: Minha pesquisa atual é justamente sobre o regime militar. Há alguns anos escolhi investir mais nos estudos sobre o regime militar e no tempo presente, na expectativa de contribuir com outros historiadores e com a historiografia do regime militar. A pesquisa enfoca as políticas dos governos militares para as universidades. Eu entrei nisso um pouco por acaso, porque há na UFMG [Universidade Federal de Minas Gerais] um arquivo legado pela ditadura, da Assessoria de Segurança de Informações [ASI], que começou a funcionar na universidade em 1971. ${ }^{1}$ O Departamento de História indicou-me para uma

\footnotetext{
${ }^{1}$ A partir de 1970 foi montado um Sistema Nacional de Informações (SISNI), tendo como peça principal o Serviço Nacional de Informações (SNI), em funcionamento desde 1964, ao qual estavam submetidos, entre outros, órgãos de espionagem e controle nos ministérios, autarquias e repartições públicas federais civis. Segundo Carlos Fico: “o órgão central de informações de um ministério civil era sua 'Divisão de Segurança e Informações’ [DSI]. Em cada órgão importante da administração pública existia uma 'Assessoria de Segurança e Informações’ (ASI), por vezes chamada de ‘Assessoria Especial de Segurança e Informações’ (AESI)”. Ver:
} 
comissão gestora desse arquivo em 2003. Tomei contato então com essa dimensão da repressão política e comecei a interessar-me em entender como a repressão política foi experimentada na vida cotidiana da universidade. Elaborei então um projeto mais amplo para estudar a repressão política nas universidades para entender o projeto modernizador que os militares implantaram nas universidades. Não é possível olhar só a dimensão repressiva e fechar os olhos para o aspecto modernizador, pois isso implica em escrever só metade da história. Acho que as duas dimensões imbricam-se: modernização e repressão. Em certo momento elas se complementam, uma leva à outra. A modernização facilitava e tornava mais legítima a repressão política. A minha pretensão nesta pesquisa é estabelecer um quadro compreensivo mais geral da questão da intervenção dos militares nas universidades. O uso que eu faço da Historia oral é para produzir uma fonte, mais uma, para proporcionar acesso ao objeto. Quando trabalhamos com a História presente, contemporânea ou recente, a História oral é fonte indispensável, porque muitas vezes os documentos tradicionais não estão disponíveis ou não são suficientes. Realizei entre 45 e 50 entrevistas e vou utilizar também entrevistas feitas por outros pesquisadores. Privilegio pessoas que foram professores ou alunos do sistema universitários nas décadas de 1960 e 1970 para compreender como viveram o período da repressão política. Muitas vezes elas complementam informações da documentação escrita, mas há ocasiões em que a documentação sugere uma coisa e o relato obtido através da História oral contradiz o documento escrito. Por exemplo, nos documentos das ASI encontrei dois ou três casos em que os órgãos de informação registravam: não se deve contratar fulano, ele tem passado comprometedor e aí fornecem a ficha, que em geral começa pelo DOPS. Por fim, há um despacho do órgão de informação: a contratação de determinado professor não é recomendada. O historiador olha para isso, sabe que nós tivemos uma ditadura, a tendência é acreditar que não houve a contratação. Mas aí você consegue uma entrevista e constata que ele foi contratado. Então, a História oral nesse caso é fundamental. E leva-me à reflexão sobre os limites do poder repressivo no contexto da ditadura militar. Tanto a História oral quanto a documentação oficial mostram que a repressão e o poder dos órgãos encarregados de controlar não era sem limites: não eram tão poderosos como supomos. E isso eu acho absolutamente fascinante, porque a documentação está mostrando um monte de exemplos de limitações de poder dos órgãos de repressão. Muitas vezes eles perdiam, e isto tem revelado que havia um jogo de disputa pelo poder que envolvia vários atores, dentro do aparelho do Estado. As entrevistas são fontes fundamentais para tratar desses processos, que

FICO, Carlos. Como eles agiam - Os subterrâneos da ditadura militar: espionagem e polícia política. Rio de Janeiro: Record, 2001. p. 83-84. 
tiveram uma dimensão nacional. Eu tenho me concentrado em entrevistas em São Paulo, Rio, algumas no Nordeste, Brasília e Minas Gerais, além de dados obtidos de outros pesquisadores. Minha pretensão não é dizer a última palavra, mas propor um modelo de análise sobre o que foi a repressão dos regimes militares nas universidades. Penso que serão indispensáveis estudos que pontuem casos, como na Universidade de São Paulo [USP], por exemplo, que tem uma riqueza tremenda, ou os casos da Universidade Federal do Rio de Janeiro [UFRJ] e da UFMG. Mas minha intenção é realizar um estudo mais abrangente. Nas minhas pesquisas sempre sou atraído por um olhar mais amplo para tentar enxergar o quadro maior. Eu não consigo tomar um tema muito monográfico, pois sou atraído por tentar comparar e entender o conjunto.

Tempo e Argumento: Como você mencionou, a ditadura militar brasileira apresentou uma preocupação com a modernização. Como, então, lidar com formas de abordar o tema que operam com modelos de análise muito abrangentes e que tendem a dar pouca atenção às singularidades do que se passou no Brasil em relação a seus vizinhos?

Rodrigo Patto Sá Motta: Acredito que uma boa opção é fazer comparações mais modestas: comparar o Brasil com a Argentina, comparar a Argentina com o Chile ou a Argentina, o Brasil e o Chile. Partir dos casos peculiares na tentativa de fazer comparações e obter uma compreensão mais geral que dê conta dessas peculiaridades. Há semelhanças e, inclusive, aprendizados mútuos entre esses regimes: há trocas de especialistas e, aliás, um dos temas interessantes é a relação da ditadura militar brasileira com as outras, porque há muitas informações que indicam a presença de militares brasileiros nos golpes vizinhos. Eu mesmo conversei com um professor que esteve preso no Estádio Nacional, no Chile, e informou-me que quem fazia a triagem dos presos era um brasileiro. Isso revela certa semelhança: as matrizes eram parecidas. Argentinos e brasileiros recebiam treinamento semelhante, por parte de franceses e norte-americanos. O tipo de violência empregado também é bem parecido. A diferença está na escala: aqui a escala da violência foi menor, isso é inquestionável. Não é tão relevante discutir qual ditadura foi mais violenta, mas o fato da violência ter afetado menos pessoas no Brasil tem implicações políticas. Isso não é algo que se deva desconsiderar. Sob o ponto de vista moral é a mesma coisa você matar trinta mil ou matar quinhentos. Mas do ponto de vista político, não: então isso não é irrelevante, tanto que trouxe desdobramentos futuros. Acredito que este tema interessa à História e às Ciências Sociais e penso que se pode compreender melhor ao realizar comparações entre os casos e evitar essas generalizações que 
resumem tudo à Doutrina de Segurança Nacional ou ao Estado burocrático-autoritário. Um dos problemas com esse conceito de segurança nacional é que, dependendo do modo como é empregado, supõe uma subserviência total ao governo dos Estados Unidos, numa estratégia que teria levado à aliança externa com os norte-americanos e à concentração das Forças Armadas ao âmbito da defesa interna. Eu acho muito simplório esse modo de compreender as relações das ditaduras com o governo norte-americano. Se assim fosse, por que a Argentina e o Chile quase entraram em guerra por causa daquelas ilhotas do Canal de Beagle? Não faz sentido na perspectiva da Doutrina de Segurança Nacional. Por que as ditaduras argentina e brasileira entraram em conflito quando da construção da Usina Hidroelétrica de Itaipu? Isso não se explica pela Doutrina de Segurança Nacional. Realizaram repressão interna, mas continuaram com a preocupação com as fronteiras e, algumas vezes, entrando em divergência com o governo norte-americano. No caso brasileiro há vários momentos de tensão: o primeiro deles foi com o próprio AI-5 [Ato Institucional Número 5], que o governo dos EUA não aprovou. Os representantes diplomáticos norte-americanos não concordaram e demonstraram isso ao suspender a venda de armas e ameaçar cortar o auxílio financeiro. Depois o governo brasileiro afastou-se da orientação militar norte-americana ao ponto de romper o acordo militar de cooperação, em 1977. Temos que parar de pensar que tudo se explica a partir da influência dos EUA. Por outro lado, os norte-americanos foram influentes e não é possível pensar as ditaduras sem essa influência, mas isso não explica tudo. Temos que investir mais na compreensão de cada um dos casos nacionais e, depois, partir para a comparação. Quando você começa a comparar, as diferenças são muito agudas na questão da repressão e no que diz respeito às políticas econômicas. A ditadura argentina desindustrializou o país, diminuiu a classe operária tradicional e implantou um sistema liberal mitigado que não chegou a ser um neoliberalismo, devido a algumas resistências no próprio Estado. O governo chileno implantou medidas neoliberais e mudou a face da economia chilena. O governo brasileiro não fez nada disso: foi um governo desenvolvimentista. Seu momento mais liberal foi o período Castelo Branco, mas nem aí foi efetivamente liberal. O governo dos EUA e o FMI, por exemplo, acharam que Castelo Branco foi tímido nas reformas liberais. Após Castelo Branco, foi implantado um modelo desenvolvimentista, com a criação de estatais, e durante todo o período houve grande industrialização. Se você comparar as três ditaduras, do ponto de vista econômico, a Argentina destruiu o modelo econômico e não colocou nada no lugar, a chilena destruiu o modelo econômico e construiu outro, e a brasileira manteve o mesmo modelo econômico e intensificou a industrialização. E isso não é algo sem consequências políticas, pois teve impactos futuros. Penso que inclusive isso tem a ver com o fim da ditadura no 
Brasil, que foi menos traumático para os militares, do que comparado à Argentina e ao Chile. No Brasil não houve nenhum militar efetivamente punido, enquanto que no Chile e na Argentina há gente sendo punida.

Tempo e Argumento: Esses limites ao autoritarismo identificados em sua pesquisa mantêm relação com o que se possa discutir em termos de culturas políticas?

Rodrigo Patto Sá Motta: Tenho proposto pensar o conceito de cultura política para explicar as diferenças entre Brasil, Argentina e Chile. Acredito que um investimento maior na utilização desse conceito ajudará a entender essas diferenças e é isso que eu estou tentando explorar nessa pesquisa sobre as universidades. Uma reflexão que estou desenvolvendo e que ainda está em elaboração é a de que a cultura política brasileira tem um traço chave: a busca da negociação, da conciliação e de arranjos que evitem rupturas. Na política brasileira é muito forte o apelo por moderação. Há momentos agudos, como no pré-64, quando vários entrevistados dizem haver sentido um clima de guerra civil e que a expectativa era de um conflito tremendo; e os golpistas pediram ajuda norte-americana porque acharam que haveria uma guerra longa. Mas daí vem um golpe sem sangue e, no final, uma negociação em que se chega a um meio termo; sem sangue é exagero, na verdade morreram dois jovens em Recife em protesto de rua, e mais gente morreu na prisão; mas para a envergadura do fenômeno, é efetivamente pouca violência para tamanha mudança política. Você compara os golpes argentinos e brasileiros do período entre as décadas de 1940 e 1960 e percebe uma nítida diferença na manifestação da violência política. No Brasil tivemos uma série de golpes: a retirada de Getúlio do poder em outubro de 1945, o episódio da crise de 1954, os conflitos contra a posse de Juscelino Kubitscheck, as tentativas de Jacareacanga e Aragarças e o golpe militar em 1964. Muitos desses golpes não provocaram sangue. Se a gente observa os golpes argentinos desse período, todos terminaram em sangue. $\mathrm{O}$ caso mais agudo e chocante é o golpe de 1955, um dos episódios para a derrubada de Perón ${ }^{2}$. Aviões bombardearam a Plaza de Mayo e, pelo que se sabe, houve centenas de mortes entre os que estavam ali concentrados para defender Perón. Com a vitória dos golpistas, Aramburu ${ }^{3}$ conduziu processos militares que levaram ao fuzilamento de apoiadores de Perón, inclusive um importante General [Juan José Valle], isso em 1956. Na Argentina havia um clima de violência política entre facções que aguçava o conflito e o ódio, o que não era resolvido na saliva, como no Brasil. Não há

\footnotetext{
${ }^{2}$ Juan Domingo Perón, militar e Presidente argentino entre 1946 e 1955 e entre 1973 e 1974.

${ }^{3}$ Pedro Eugenio Aramburu, militar e Presidente argentino entre 1955 e 1958.
} 
este histórico no Brasil e isso estimulou os atores políticos à moderação e à auto-contenção. Por que pensar em fuzilar o Miguel Arraes, preso em Pernambuco, se isso não tinha paralelo na história recente? Por que inaugurar uma violência desse tipo, que no futuro pode trazer implicações? No Brasil atuavam forças e tradições que estimulavam a moderação, enquanto na Argentina o estímulo era para a violência. Quando os Montoneros ${ }^{4}$ fuzilaram o general Aramburu, estavam cobrando a conta dos militares peronistas da década de 1950 e, depois, os militares argentinos cobraram a vida de Aramburu e de outros. Então, na cultura política argentina há uma violência mais entranhada. Se eu fosse especular mais, mencionaria inclusive a literatura argentina, na qual é muito forte a figura do duelo, como em alguns dos contos mais importantes de José Luís Borges. Então, a ideia seria a de que nas culturas políticas de cada país, há certas tradições que influenciam o comportamento dos atores sociais, mesmo em momentos de violência aguda. O que estou encontrando no estudo das universidades durante a ditadura confirma isso. Em vários momentos, as autoridades foram envolvidas no jogo da negociação e da moderação. Mesmo com a opção de punir ou de demitir, há sugestões para negociar e tentar um acordo. Os militares poderiam estar incomodados com alguém, mas ao invés de demissão pode-se enviá-lo para fazer doutorado nos EUA, depois ele volta. Então é outro tipo de negociação: pede-se para parar de falar em sala de aula coisas inconvenientes. Há episódios de negociação que são interessantíssimos e surpreendentes, quando comparados com as universidades argentinas, as quais viveram um expurgo violento e nas quais os alunos eram obrigados a cortar o cabelo e as meninas não podiam usar saias curtas. Praticamente foram proibidos cursos de Ciências Sociais e o marxismo foi banido como uma coisa demoníaca. No Brasil, as Ciências Sociais foram vigiadas, algumas autoridades militares pressionaram contra o estudo do marxismo, mas não houve um banimento da cultura marxista. Era uma ditadura anticomunista em que as universidades públicas toleravam Marx e com muitos professores marxistas. Vários professores marxistas não foram expurgados: houve demissões, mas não generalizadas. Professores marxistas, em que pese toda a vigilância, foram contratados, mesmo com os órgãos de informação sabendo o que representavam aquelas pessoas. Esses foram momentos de negociação. Alguém faz um arranjo: fulano de tal pode, eu protejo, porque ele não é assim tão perigoso. O reitor participa do acordo, ou um diretor ou, às vezes, um professor muito poderoso. Há vários mecanismos de negociação que moderam a repressão política. No caso

\footnotetext{
${ }^{4}$ Movimiento Peronista Montonero, que atuou na Argentina nas décadas de 1960 e 1970 e adotou práticas de guerrilha urbana.
} 
da Argentina não se encontra esse tipo de arranjo. Então, eu aplico o conceito de cultura política como uma possibilidade para aprofundar o entendimento dessas diferenças.

Tempo e Argumento: Mas no caso do emprego do conceito de cultura política, como resolver limitações que podem tornar o estudo muito especulativo ou normativo? No caso específico dos mecanismos de moderação mobilizados durante a ditadura, não se poderia entender que tais negociações funcionavam apenas entre segmentos de classe média e que frequentavam a universidade?

Rodrigo Patto Sá Motta: Penso que a historiografia pode dar sua contribuição e buscar pesquisas mais agudas para entender o funcionamento dessa máquina repressiva para sair da generalização e da especulação. O emprego que faço de aspectos da cultura política brasileira é antigo em nosso pensamento social. Não estou inventando nada. Mas a especulação e o ensaísmo são muito interessantes, porque nos estimulam à pesquisa e sugerem caminhos a serem explorados. O problema exatamente é sair do ensaio. Na pesquisa que desenvolvo atualmente eu tento fazer isso e encontro vários casos. Certos reitores, ao mesmo tempo, cooperavam com o Estado e negociavam com professores e alunos para tentar moderar a repressão. Quando não era possível, sobrevinha a repressão. Mas essa moderação funciona exatamente porque a política brasileira é restrita a certos círculos: é uma política elitizada. Quando entra o elemento popular é mais difícil encontrar iniciativas para negociar, pois há um potencial disruptivo. Mas quando se trata de negociar com pessoas que são de oposição, são de esquerda, mas estudaram no mesmo colégio de tal coronel ou é primo de algum militar conhecido, a negociação ocorre com mais facilidade. Acredito que essa moderação tem a ver com laços familiares e pessoais, como afirma Roberto Da Matta: na política brasileira impera mais a casa do que a rua. Muito mais as relações familiares, laços tradicionais de família, de aliança, de escolaridade, é que interferem no jogo político. As universidades foram palcos favoráveis para esse tipo de arranjo, por causa da presença desses laços entre uma população elitizada. A política brasileira é, tradicionalmente, de exclusão. A questão é saber se é só exclusão ou se também há auto-exclusão. Eu estou cada vez mais insatisfeito com a ideia de que as classes populares no Brasil não participam politicamente porque são excluídas: eu não sei se isso explica tudo. Acredito que isso não explicaria o porquê de as classes populares da Bolívia terem se imposto ao Estado ou o povo mexicano, que fez revoluções e se incluiu, enquanto nossa população aceitou esse modelo de exclusão da política. Acredito que isso, 
inclusive, é um tema para ser pensado na chave de cultura política. Mas a política brasileira tem esses traços exatamente porque é muito elitizada.

Tempo e Argumento: Esses mecanismos de moderação e as diferenças entre as ditaduras da América do Sul também podem ser pensados para o caso das relações entre Igreja Católica e governos?

Rodrigo Patto Sá Motta: Como é amplamente sabido, a Igreja da Argentina apoiou quase unanimemente o golpe e a ditadura. Até hoje, nas lutas em torno da memória do período, certos líderes religiosos seguem afirmando que não houve massacre. A Igreja brasileira foi bastante diferente. Um aspecto que considero importante pensar é o da formação dos militares argentinos e brasileiros. Os argentinos foram muito mais católicos e integristas, imbuídos dos valores e da moral católica. O altar estava muito mais próximo da caserna. Os militares brasileiros, desde o final do século XIX, tiveram uma influência positivista muito forte, o que os afastou um pouco da Igreja. O Exército brasileiro nunca foi tão próximo da Igreja quanto o argentino. É o caso do próprio Presidente Ernesto Geisel. Imagina se isso seria possível na Argentina: um Presidente militar que não fosse católico? Improvável.

Tempo e Argumento: O divórcio no Brasil foi aprovado durante o governo Geisel, em 1977.

Rodrigo Patto Sá Motta: Além disso, naquele momento, a Igreja brasileira estava criando muitos problemas para o regime, então havia interesse em dar uma resposta. Na Argentina houve uma ligação profunda entre a Igreja e o regime e este é um tema a ser mais explorado quanto às diferenças entre o caso brasileiro e o argentino. Voltando à formação diferenciada: algo que aconteceu no Brasil, e não na Argentina, foi o fenômeno da “esquerdização” dos militares. Aqui houve momentos de levas de militares de esquerda: comunistas, nacionalistas de esquerda, influenciados pela linha do Brizola, por Goulart e os Generais do povo. A Argentina não vivenciou nada disso. O Exército argentino do século XX é de direita ao longo de todo o período: o Exército atuou sempre na repressão ao lado da Igreja e das forças mais conservadoras. No Brasil, contudo, houve momentos em que o Exército se cindiu, quando a esquerda chegou a anunciar: “o Exército é do povo”. Em 1964, o "Exército do povo” promoveu um golpe contra o povo... Mas, de fato, houve uma tradição de politização das Forças Armadas à esquerda. Acredito que seria interessante explorar isso pelo viés das 
origens positivistas: esta é uma porta pra entender porque nas instituições militares tanta gente aderiu a ideias modernas, ideias questionadoras da tradição, principalmente no que toca aos valores morais.

Tempo e Argumento: Explorando um pouco mais a questão de classe, no Brasil há poucos embates históricos entre as elites, enquanto há uma dificuldade de enraizamento do pensamento de esquerda entre as camadas populares. No caso Argentino, parece haver diferenças significativas neste aspecto. Quais as implicações disso?

Rodrigo Patto Sá Motta: Segmentos da esquerda argentina conquistaram uma base popular e também houve uma “esquerdização” do peronismo, que acredito ter sido realmente o que assustou os militares. Penso que isso tem implicações na violência política. O que o exército argentino enfrentava? Um peronismo enraizado e uma guerrilha muito poderosa. O que o exército brasileiro enfrentava? Após o golpe ficou a sensação de que a esquerda brasileira era um blefe. Acredito mesmo que é um pouco exagerada essa visão, porque não acho que a esquerda fosse tão frágil assim, mas eles não encontraram resistência efetiva. Então não houve o impulso de cometer a violência para amedrontar o adversário e desmobilizá-lo. Acredito que a estratégia terrorista por parte do Estado não foi algo indispensável no Brasil, pelo menos não em escala aguda. Na Argentina foi o oposto. E o caso do Chile de Pinochet? O Partido Comunista e o Socialista eram muito fortes, ambos marxistas. O governo de Allende ${ }^{5}$ fazia uma transição para o socialismo de fato. Então, num quadro como este, os militares fizeram ações terroristas para controlar a massa popular que tinha uma afinidade com a esquerda. No Brasil, a situação é diferente. Exatamente por essa grande exclusão da população, ou autoexclusão, ela não representava um risco tão grave assim para o Estado. Então, cabe olhar de novo essa questão das tradições políticas: a esquerda brasileira, em 1964, era muito menos ameaçadora do que a esquerda chilena em 1973 e, talvez, menos do que a Argentina. O que diferencia o Brasil de 1964 da Argentina de 1976 é que aqui a esquerda era aliada do poder: o Goulart abriu certo espaço para a esquerda e foi isso que efetivamente assustou quem apoiou o golpe, não por perceber enraizamento social da esquerda, mas por perceber que ela havia chegado ao poder. Foi a primeira vez na História brasileira. A esquerda nunca fora bem recebida nos palácios (salvo alguns intelectuais), pelo contrário, sofreu sempre a repressão. Aí vem o Goulart e começa a abrir espaço no governo para gente de esquerda e para marxistas,

\footnotetext{
${ }^{5}$ Salvador Allende Gossens, médico e Presidente do Chile entre 1970 e 1973. Foi deposto por um golpe militar conduzido pelo General Augusto Pinochet, em 1973.
} 
como o General Assis Brasil e Darci Ribeiro, que não era mais do Partido Comunista, mas ainda era considerado marxista. Além de outros cargos importantes no segundo escalão do governo. Isso assustou muito. Entre os golpistas, houve os que diziam que havia o risco de uma “esquerdização” de cima para baixo. Do controle do Estado em direção à sociedade.

Tempo e Argumento: Ao final do regime militar no Brasil eclodiram novos movimentos sociais. Como relacionar o tema da violência política com o do surgimento de novos personagens na cena pública brasileira na década de 1970?

Rodrigo Patto Sá Motta: A participação mais intensa dos movimentos sociais também diferencia o Brasil de outros países. Ao final da ditadura brasileira ocorreu uma eclosão de movimentos sociais muito fortes, embora seja meio exagerada essa ideia de novos movimentos sociais, mas eram de fato intensos e interpelaram o regime. Na Grande São Paulo começa a surgir o fenômeno grevista e isso se torna um problema social e político muito grave e põe o governo diante da repressão a setores populares. Mas ainda assim eu vejo uma auto-contenção da parte do Estado. Houve um episódio famoso: o cerco a São Bernardo em 1980. O sindicato fez uma assembleia e as forças militares cercaram e havia uma sensação que ocorreria um massacre. O que aconteceu? Não ocorreu massacre algum. Houve uma negociação, a polícia saiu e fizeram um arranjo, um acordo pra evitar o massacre. Poderia ter sido um banho de sangue, se alguém tivesse dado ordem para atirar. Foi proposto um acordo e a liderança operária, até certo ponto, colaborou em não instigar um confronto. Prevaleceu a moderação: não houve violência em larga escala devido à negociação política. Outro aspecto a pensar é o da violência de tipo comum praticada pelo Estado, não exatamente uma violência com motivação política. Durante a ditadura houve um aumento da violência policial, com a ação de esquadrões da morte e de eliminação de criminosos comuns. Provavelmente houve um aumento da violência nas prisões contra condenados comuns. A ditadura aumentou a violência comum, porque os policiais passaram a ter uma chancela do Estado para agir de maneira violenta. Sabia-se que a tortura ocorria em quartéis e delegacias. Então, num ambiente desses, pareceu normal à polícia aumentar a violência. Rompeu-se inclusive uma barreira tradicional brasileira que foi a de cometer violência contra filhos das classes média e alta. Nesse ambiente, em uma "blitz" um filho de classe média pode ser espancado se for encontrado com maconha. Mas, no caso da violência política, em que medida foi ampliada pelo Estado? Meu argumento deve ser colocado à prova: houve forças que promoveram uma moderação nessa violência e que instigaram à contenção da possibilidade repressiva que 
estava ao alcance do Estado. Mesmo episódios que foram considerados violentos, como a chamada invasão policial da PUC [Pontifícia Universidade Católica] em São Paulo, durante um encontro estudantil em 1977. Houve negociações, tratativas e conversas. Por fim, a polícia entrou, bateu em um bocado de gente, muitos foram presos, mas não foi tão violento quanto poderia ter sido em outro contexto. Porque foi um desafio ao governo que havia proibido o evento. Tentou-se realizar esse evento também em Belo Horizonte, na universidade: a polícia impediu e o reitor também foi tentar negociar para evitar violência maior. Os estudantes foram presos e depois soltos. Em São Paulo, a Igreja bancou o evento na PUC. Enfim, é um tema que merece mais pesquisas para tentar encontrar uma explicação para o comportamento da ditadura brasileira, inclusive a quantidade bem menor de mortos no Brasil em relação à Argentina ou ao Chile durante o período. Mas quero deixar claro que isso não diminui em nada a condenação política e moral da violência praticada pelo Estado militar. Meu argumento é que essas peculiaridades do quadro político brasileiro devem ser explicadas, inclusive para entender a natureza da transição à democracia, e por que a atitude atual da sociedade em relação ao regime militar, em que se vê muito desinteresse e apatia.

Tempo e Argumento: E a repressão no meio artístico e cultural? Cabe lembrar que não houve uma repressão violenta contra músicos populares brasileiros como ocorreu na Argentina ou no Chile.

Rodrigo Patto Sá Motta: Basta comparar com o que ocorreu com Victor Jara, no Chile. ${ }^{6}$ No caso brasileiro não há um mártir da música. Há inclusive os que contribuíram com o regime. Há o caso polêmico de Wilson Simonal. Enfim, de fato, a repressão por lá foi muito mais disseminada. Se tomarmos o caso de jornalistas: no Brasil morreu Herzog ${ }^{7}$ e há outros casos de jornalistas de esquerda também assassinados, mas estes não pelo exercício da profissão e sim por pertencerem a organizações clandestinas. Na Argentina morreram 80 jornalistas, alguns deles não por oposição do governo, mas como parte de lutas internas de facções do regime. No Brasil a elite artística, intelectual e política foi atingida de uma maneira mais moderada. Isso marcou a transição brasileira ao final da ditadura, porque o acúmulo de ódio não era tão intenso quanto na Argentina. Foi viável negociar uma saída do regime autoritário que preservasse os militares de punição. Na Argentina de 1983, isso era inviável. Com a

\footnotetext{
${ }^{6}$ Músico, compositor e ativista político assassinado em 1973 durante a repressão que se seguiu ao golpe militar no Chile.

${ }^{7}$ Vladmir Herzog, jornalista assassinado em 1975 no quartel-general do II Exército, em São Paulo.
} 
derrota na Guerra das Malvinas, o descalabro econômico e aquela tremenda quantidade de mortos, como negociar? No caso brasileiro foi viável a negociação e parte da estratégia militar foi a de sair mantendo algum controle.

Tempo e Argumento: No prefácio do livro “Jango e o golpe de 1964 na caricatura”, 8 você afirma ter a intenção de despertar o interesse do grande público. Acredita ser possível que a historiografia brasileira veicule suas produções entre um público mais amplo e concorra, por exemplo, com abordagens jornalísticas?

Rodrigo Patto Sá Motta: Este é um tema que interessa a todos nós, historiadores. Na verdade, foi uma aposta, pois não escrevi o livro pensando no grande público, mas nos pares acadêmicos. Defendi uma tese no livro, porém, gostaria que chegasse ao grande público, pois caricatura é um tema popular. Mas a ideia é atender primeiramente o mundo acadêmico. Concorrer com os jornalistas-historiadores é muito complicado, porque significaria certo descuido em relação ao público acadêmico. Eles são grandes vendedores de livros, como Elio Gaspari ou Laurentino Gomes, entre outros, mas nós historiadores temos uma trava que é a nossa carreira e os nossos pares. Este é o nosso mundo, onde nos movemos e que estabelece parâmetros de atuação e impõe limites. Nós corremos um risco, se quisermos chegar ao grande público, de sermos atacados na nossa corporação, de não sermos bem recebidos. $\mathrm{O}$ jornalista não tem esse problema, não tem uma corporação vigilante para verificar se está abordando a fonte ou o conceito histórico adequadamente e, assim, tem liberdade para chegar ao grande público. Inclusive, muitas vezes, esses jornalistas não apresentam as fontes que usam e as empregam como bem entendem. Enquanto nós, quando fazemos entrevistas, deixamos a gravação e a transcrição em local público para quem quiser acessar. Somos obrigados a ter cuidado com o uso de conceitos, de interpretações, e a manter diálogo com a bibliografia. A escrita do historiador acadêmico é dificilmente popularizável. Acredito ser importante para os historiadores acadêmicos preocupar-se com a produção de conhecimento novo e consistente. Como isso chegará ao grande público é outra discussão: pode ser através do historiador ou do jornalista. Somos pagos, em geral pelo Estado, para produzir conhecimento e para formar estudantes. Este livro, em particular, talvez tenha a possibilidade de chegar ao grande público, e isso me deixaria contente. Publiquei outro livro de divulgação

\footnotetext{
${ }^{8}$ MOTTA, Rodrigo Patto Sá. Jango e o golpe de 1964 na caricatura. Rio de Janeiro: Jorge Zahar, 2006.
} 
sobre a Segunda Guerra Mundial, escrito com um colega. ${ }^{9}$ Há outro, de introdução à História dos partidos políticos, que é um livro voltado para a formação da graduação. ${ }^{10}$ Entre livros mais acadêmicos, este com temática nas caricaturas políticas em 1964, vendeu mais, mas muito longe ainda de ser algo popular. Interessante que teve uma boa repercussão entre os caricaturistas e alguns deles ficaram felizes por seu trabalho ser objeto de estudo acadêmico. Eu tive muito mais retorno deles do que de historiadores, mesmo porque no nosso meio o retorno tende a demorar um pouco. Percebi que o livro sobre anticomunismo no Brasil, publicado em 2002, estava sendo muito bem recebido, uns três ou quatro anos depois. ${ }^{11}$ Demora até alguém incorporar e aparecer em citação. Tenho a impressão que muita gente que sabe que eu escrevi um livro sobre anticomunismo não tem a menor ideia que eu escrevi um livro sobre caricatura. Então, a recepção dos trabalhos que publicamos é processo lento. Os jornalistas estão aproveitando um contexto em que há um interesse popular pela História. Eu acredito que não devemos ver isso como ameaça: de certo modo, é até bom para a área, porque ajuda a divulgar e a criar no público o gosto pela História. Alguns desses bons jornalistas usam historiadores como fonte ou procuram a assessoria de especialistas.

Tempo e Argumento: Quais as potencialidades da utilização de caricaturas, cartuns, charges, quadrinhos, dentre outras produções gráficas, como documentação para o trabalho historiográfico?

Rodrigo Patto Sá Motta: A caricatura como fonte histórica continua a me fascinar. A caricatura é uma fonte muito interessante para pensar o debate político e a relação da imprensa com o poder e com a política. Mesmo que a caricatura, muitas vezes, reproduza argumentos desenvolvidos nos textos, ou seja, transforma em registro visual o que foi escrito. Ainda assim é uma fonte interessantíssima porque os recursos de que o artista dispõe para fazer uma representação política são muito ricos e livres, a não ser pelas convenções da própria arte. O caricaturista dispõe de determinadas convenções visuais para ser entendido, quando quer significar alegria ou medo, por exemplo. Usa metáforas que são tradicionais: carro como poder ou cachorro como ameaça. Além do mais, há convenções gráficas que

\footnotetext{
${ }^{9}$ MOTTA, Rodrigo Patto Sá; ARNAUT, Luiz. A Segunda Grande Guerra: do nazi-fascismo à guerra fria. São Paulo: Atual, 1994.

10 MOTTA, Rodrigo Patto Sá. Introdução à História dos partidos políticos brasileiros. Belo Horizonte: Ed. UFMG, 1999.

${ }^{11}$ MOTTA, Rodrigo Patto Sá. Em guarda contra o perigo vermelho: o anticomunismo no Brasil. São Paulo: Perspectiva; Fapesp, 2002.
} 
devem ser respeitadas para não ferir o gosto ou a moral, uma preocupação principalmente da grande imprensa.

Tempo e Argumento: Esses limites não os deixaram explorar, como você aponta no livro, o fato de João Goulart não ter os movimentos completos de uma de suas pernas, naquele momento de grande radicalismo, em 1964.

Rodrigo Patto Sá Motta: Houve certo respeito. Tenho a impressão que era uma questão de gosto. Seria grotesco demais e passaria do limite do bom gosto explorar o Presidente como um homem coxeando. João Goulart foi chamado de tudo: burro, comunista, corrupto, mas não foi chamado de coxo. É a questão do limite do grotesco. Isso é interessante porque a caricatura é uma arte grotesca, mas a grande imprensa estabelece limites. Alguns caricaturistas, contidos quando em atuação na grande imprensa, soltaram-se quando foram para a imprensa alternativa. É interessante comparar o que o cartunista Henfil publicou no Pasquim e o que publicou no "Jornal do Brasil”, por exemplo. Não foi exatamente a mesma coisa. Os que liam os alternativos queriam justamente sair dos limites e encontrar elementos mais questionadores. A caricatura lá pelos séculos XVI e XVII era muito mais grotesca. Há uma pesquisa fantástica sobre caricaturas e charges na Revolução Francesa e os temas são escandalosos: escatologia, sexo... ${ }^{12}$

Tempo e Argumento: Como você acompanha a questão do acesso aos documentos produzidos durante a ditadura pelo aparato repressivo e a procura pela abertura dos arquivos? Há o risco de que parte importante deles tenha sido destruída?

Rodrigo Patto Sá Motta: Existem acervos militares ainda não abertos. Devemos chamar a atenção da opinião pública e cobrar do governo o paradeiro desses arquivos. O Governo Federal tomou iniciativas interessantes, mas algumas complicadas. Pedem às pessoas para apresentarem documentos sobre o regime militar. Mas quem tem esses documentos é o Estado! Aliás, foi patética a campanha na televisão, dirigida ao público e dizendo: se você tiver documentos sobre a repressão entregue ao Estado. Mas os documentos estão com as Forças Armadas, que fazem parte do Estado: os arquivos do Centro de Informações do Exército, que estão em algum lugar, da Marinha, da Aeronáutica, além de outros que eram de

12 BAECQUE, Antoine de. La caricature révolutionnaire. Paris: CNRS, 1988; LANGLOIS, Claude. La caricature contre-révolutionnaire. Paris: CNRS, 1988. 
âmbito ministerial. O Ministério da Educação [MEC] tinha uma Divisão de Segurança das Informações [DSI]. Eu conheci um funcionário do Ministério que era da área de informações, e perguntei a ele: o senhor tem alguma ideia do que foi feito com o arquivo da DSI do MEC? Ele respondeu: um caminhão militar levou os arquivos na noite em que o governo Fernando Collor decretou, em 1990, a extinção do SNI [Serviço Nacional de Inteligência] e das DSI. Eu perguntei qual o destino dos documentos e ele disse: não sei. Então, os documentos estão com os militares. E isso é algo que vai continuar pendente e o governo vai ter que se posicionar. Não creio que os documentos tenham sido destruídos. São muito valiosos: são, inclusive, recursos de poder, inclusive por haver informação sobre gente importante. Eu creio que nem todos foram destruídos porque podem ser usados como estratégia de chantagem ou pressão. Há casos em que houve destruição. Há muitas indicações de que a documentação do DOPS do Rio Grande do Sul realmente foi destruída e, aparentemente, sem cópia. Há outros lugares em que se alega terem sido destruídos, mas há cópias. Por exemplo, em Minas Gerais a polícia afirmou que queimou a documentação do DOPS, mas os microfilmes foram recuperados, uma parte, ao menos. Então é preciso investigar e não confiar até ter certeza do que aconteceu com essas informações. O governo tem receio das Forças Armadas. Há o medo do fantasma do golpe, que eu acho absolutamente desproposital, porque não ocorrerá golpe militar, não há apoio e os militares não são burros. Houve o golpe de 1964 porque tiveram um apoio tremendo da opinião pública, principalmente na classe média e alta. Acredito que vale a pena cobrar isso dos militares. Mas há algo que devemos sempre lembrar: no caso do Brasil, nós temos muitos documentos. Se você comparar o Brasil com Argentina, Chile e Paraguai, nós somos o país que mais possui documentos sobre a repressão. Um acervo de que eles não dispõem. O único acervo relevante dos argentinos no que toca a documentos oficiais é o da Província de Buenos Aires, que tinha uma divisão parecida com o DOPS, enquanto nós temos os documentos do SNI no Arquivo Nacional, em Brasília, os quais chegaram a provocar uma polêmica por causa do contexto das últimas eleições presidenciais. Interpretou-se que o arquivo quis proteger a candidatura de Dilma Rousseff e restringiu acesso durante o período eleitoral e a imprensa interessou-se apenas por causa da eleição. Porque essas restrições de acesso são feitas por vários arquivos há muito tempo. Há anos atrás tentei pesquisar no DOPS de Pernambuco, que está no Arquivo do Estado, e a resposta foi: só permitimos acesso aos interessados diretos nos processos. O Arquivo Público do Rio de Janeiro até hoje restringe o acesso a prontuários pessoais produzidos pela polícia. O Arquivo Nacional operava uma política ambígua em relação a isso. No início de minha pesquisa, encontrei uma política mais liberal: pedi documentos sobre universidades e eles começaram a enviar na íntegra. Depois, 
começaram a restringir e mandaram o segundo bloco de documentos com os nomes das pessoas tarjados. Isso, aliás, deve ter dado um trabalho tremendo para o funcionário. De fato, então, é uma política meio errática. Atualmente, cada gestor de arquivo tenta interpretar as leis de maneira própria. Acredito que seja necessária uma discussão nacional para criar uma política geral, porque é um acervo extraordinário. Só no acervo do SNI, ao pedir informações sobre universidades, apareceram dois mil registros, ou seja, dois mil processos. Imagina a infinidade de outros assuntos. É um manancial de pesquisa extraordinário. É preciso estabelecer uma política clara sobre isso porque é importante não só do ponto de vista acadêmico, quanto do ponto de vista político. 